\title{
PENGARUH KONEKSI POLITIK, INTENSITAS ASET TETAP, KOMISARIS INDEPENDEN, PROFITABILITAS DAN LEVERAGE TERHADAP TAX AVOIDANCE
}

\author{
Sahrir $^{1 *}$, Sultan ${ }^{2}$, Sofyan Syamsuddin ${ }^{3}$ \\ ${ }^{1,2,3}$ Fakultas Ekonomi dan Bisnis, Universitas Muhammadiyah Palopo \\ sahrir@umpalopo.ac.id ${ }^{1}$,sultan@umpalopo.ac.id ${ }^{2}$, sofyansyam@umpalopo.ac.id ${ }^{3}$
}

\begin{abstract}
ABSTRAK
Penelitian yang dilakukan bertujuan untuk menguji dan mengetahui pengaruh koneksi politik, intensitas aset tetap, komisaris independen, profitabilitas dan leverage terhadap tax avoidance. Metode penelitian yang digunakan adalah metode kuantitatif. Data yang digunakan adalah data sekunder berupa laporan keuangan perusahaan sektor perbankan yang terdaftar di Bursa Efek Indonesia selama 5 periode pengamatan yaitu antara tahun 2014-2018 yang diperoleh dari website resmi BEI dan website dari masing-masing bank. Penentuan sampel menggunakan purposive sampling sehingga diperoleh laporan keuangan yang memenuhi kriteria penelitian berjumlah 172 pengamatan. Teknik analisis data yang digunakan adalah analisis regresi linier berganda. Hasil Penelitian menunjukkan bahwa secara simultan variabel koneksi politik, intensitas aset tetap, komisaris independen, profitabilitas dan leverage berpengaruh terhadap tax avoidance. Secara parsial variabel koneksi politik, intensitas aset tetap, profitabilitas dan leverage berpengaruh terhadap tax avoidance. Sedangkan variabel komisaris independen tidak berpengaruh terhadap tax avoidance.
\end{abstract}

Kata Kunci: Tax Avoidance, Koneksi Politik, Intensitas Aset Tetap, Komisaris Independen, Profitabilitas,

Leverage.

\begin{abstract}
Tax avoidance is a business that is conducted legally by the company by utilizing existing loopholes in the tax regulations with the aim of minimizing or even avoiding tax payments. This research aimed to know and analyze the effect of political connections, fixed assets intensity, independent commissioners, profitability and leverage to tax avoidance. The method used is quantitative, where the data used is secondary data formed as financial statements of banking sector companies listed on the Indonesia Stock Exchange for the period 2014-2018. The sample determination used purposive sampling, so obtained financial statements that meet the research criteria of 172 observations. The data analysis technique used multiple linier regression analysis. The research result showed that political connections, fixed assets intensity, profitability and leverage affected to the tax avoidance. While independent commissioners is not affected to the tax avoidance.
\end{abstract}

Keywords: Fixed asset intensity, Independent commissioners, Leverage, Political connections, Profitability, Tax avoidance.

\section{PENDAHULUAN}

Pajak memiliki peranan yang sangat penting dalam kehidupan bernegara khususnya dalam melaksanakan pembangunan, karena pajak adalah salah satu sumber pendapatan negara untuk membiayai pengeluaran negara. Indonesia merupakan negara yang sedang berkembang, dimana sumber penerimaan utamanya berasal dari sektor perpajakan. Menurut Damayanti dan Susanto (2015) pajak yang dipungut oleh negara difungsikan sebagai sumber dana yang diperuntunkan bagi pembiayaan pengeluaran pemerintah dan difungsikan sebagai alat untuk mengatur dan melaksanakan kebijakan dibidang sosial dan ekonomi serta digunakan untuk sebesar-besarnya kemakmuran rakyat.

Dalam Pendapatan dan Belanja Negara (APBN) tahu 2018 total pendapatan diproyeksikan mencapai $1.894,7$ triliun rupiah, dimana $1.618,1$ triliun rupiah $(85,4 \%)$ 
bersumber dari pajak, 275,4 triliun rupiah bersumber dari penerimaan bukan pajak dan sebesar 1,2 triliun rupiah dari dana hibah (www. kemenkeu.go.id). Berikut ini disajikan target dan realisasi penerimaan pajak dalam lima tahu terakhir:

Tabel 1 : Target dan Realisasi Penerimaan Pajak

\begin{tabular}{cclc}
\hline Tahun & \multicolumn{1}{c}{ Target } & \multicolumn{1}{c}{ Realisasi } & Presentase \\
\hline 2014 & Rp 1.072,38 triliun & Rp 985,13 triliun & $91,86 \%$ \\
2015 & Rp 1.294,26 triliun & Rp 1.060,86 triliun & $81,97 \%$ \\
2016 & Rp 1.355,20 triliun & Rp 1.105,73 triliun & $81,59 \%$ \\
2017 & Rp 1.283,57 triliun & Rp 1.151,03 triliun & $89,67 \%$ \\
2018 & Rp 1.424,00 triliun & Rp 1.315,51 triliun & $92,24 \%$ \\
\hline
\end{tabular}

Sumber: Kementerian Keuangan, 2020

Tabel di atas menunjukkan bahwa target penerimaan pajak dalam lima tahun terakhir mengalami peningkatan kecuali di tahun 2017. Sementara realisasinya terus mengalami kenaikan, disisi lain persentase penerimaan pertahunnya mengalami fluktuasi dimana tahun 2015 dan 2016 mengalami penurunan, namun dalam dua tahu terakhir kembali menunjukkan pengingkatan. Hal tersebut terjadi karena besarnya peresentase kenaikan target penerimaan pajak tidak diimbangi dengan realisasi penerimaan pajak itu sendiri.

Untuk memaksimalkan penerimaan disektor perpajakakan dilakukan reformasi perpajakan dengan dikeluarkannya undang-undang perpajakan tahu 1998, sistem perpajakan mengalami perubahan dari sistem office assessment menjadi selft assessment (Wicaksono, 2017). Dengan perubahan sistem tersebut wajib pajak memiliki hak dan kewajiban untuk menghitung, membayar dan melaporkan kewajiban perpajakannya sendiri. Di tahun 2008 pemerintah kembali melanjutkan reformasi perpajakan untuk memaksimalkan pendapatan dari sektor perpajakan dengan merevisi undang-undang No.36 tahun 2008 tentang penurunan tarif pajak. Sebelumnya pada tahun 2003 Drektur Jendral pajak telah mengeluarkan surat No.S14/PJ.7/2003, Indonesia melakukan intensifikasi dan ekstensifikasi untuk memaksimalkan penerimaan sektor perpajakan.

Indonesia memiliki tingkat kepatuhan pajak yang tergolong rendah, tercermin dari tax ratio pada tahun 2018 yang hanya sebesar 11,5\% jauh tertinggal dibarisan menengah yaitu sebesar $14-15 \%$ dan negara maju sebesar 24-26\%. Penyebab rendahnya tax ratio adalah karena rendahnya penerimaan pajak itu sendiri. Kondisi ini mengindikasikan masih banyak wajib pajak yang belum memenuhi kewajiban perpajakannya. Adanya perbedaan kepentingan antara wajib pajak dan pemerintah, wajib pajak berusaha agar membayar pajak sekecil-kecilnya karena membayar pajak berarti mengurangi kemampuan ekonomis wajib pajak (Permata, Nurlaela, \& Wahyuningsih, 2018). Perbedaan perspektif itu kemungkinan akan mempengaruhi kepatuhan wajib pajak dalam melaksanakan kewajiban perpajakannya.

Salah satu bentuk ketidakpatuhan yang dapat dilakukan oleh perusahaan dalam meminimalkan beban pajaknya adalah dengan melakukan praktik tax avoidance. Perusahaan yang menerapkan tax avoidance tidak selalu gagal karena ada banyak ketentuan pajak yang mendorong perusahaan untuk mengurangi pajak, ditambah dengan grey area, terutama untuk transaksi yang kompleks (Dyreng, Hanlon, dan Maydew, 2010). Praktik tax avoidance mungkin diinginkan oleh pemegang saham untuk meningkatkan nilai perusahaan. Akibatnya 
praktik tax avoidance sah secara hukum sehingga pemerintah tidak dapat memberikan sanksi bahkan ketika ada indikasi skema penghindaran pajak yang akan dilakukan oleh perusahaan.

Praktik tax avoidance merupakan masalah yang unik dan rumit, satu sisi diperbolehkan namun dilain sisi tidak diharapkan pemerintah karena dapat mengurangi penerimaan negara. Untuk meminimalisir praktik tax avoidance dalam pasal 18 undangundang pajak penghasilan telah dikenal peraturan specific anti avoidance rule. Namun karena semakin kompleksnya skema yang digunakan tidak mungkin mencakup seluruh jenis transaksi yang berkaitan dengan tax avoidance. Indonesia telah setuju untuk menetapkan The Automatic Exchange of Information (AEOI). Selain itu pemerintah juga telah membuat peraturan pengganti undang-undang No.1 tahun 2017 tentang akses informasi keuangan untuk keperluan perpajakan.

Koneksi politik merupakan salah satu yang dianggap memiliki pengaruh terhadap praktik tax avoidance khususnya pada negara berkembang seperti indonesia. Untuk memahami peran koneksi politik terhadap praktik tax avoidance Abdul Wahab (2017) mengungkapkan kebijakan yang tumpang tindih antara dimensi publik dan pribadi dari koneksi politik menunjukkan bantuan yang diberikan kepada perusahaan dalam bentuk keringanan pajak dan kemungkinan dana talangan bebas pajak. Perusahaan yang terhubung secara politis akan mendapatkan manfaat dari koneksi mereka terutama di negara dengan tingkat korupsi yang tinggi. Sejalan dengan itu Sudibyo dan Jinfu (2016) menjelaskan perusahaan yang mempekerjakan komisaris independen yang terhubung secara politik lebih cenderung menunjukkan perilaku penghindaran pajak.

Tax avoidance juga dimungkinkan terjadi karena faktor intensitas aset tetap. Aset tetap adalah aset yang dimiliki perusahaan yang digunakan dalam kegiatan operasional dan memiliki batas masa manfaat dalam penggunaanya yang disertai dengan adanya depresiasi yang bisa dimanfaatkan untuk meminimalkan beban pajak. Semakin besar intensitas aset tetap yang dimiliki perusahaan, semakin besar pula beban penyusutan yang akan didapatkan dan semakin besar kemungkinan beban penyusutan akan mengurangi beban pajak perusahaan dalam rekonisiliasi fiskal (Purwanti dan Sugiyarti, 2017).

Komisaris independen merupakan salah satu bagian penting dalam penerapan Good Corporate Governance (GCG) khususnya pada perusahaan publik. Komisaris independen adalah seseorang yang tida memiliki hubunga dengan kepentingan pemegaang saham pengendali, direksi atau dewan komisaris. Wijayanti dan Merkusiwati (2017) mengungkapkan jumlah dewan komisaris independen yang semakin banyak dapat mengawasi manajemen agar dapat mematuhi peraturan perundang-undangan yang berlaku sehingga dapat meminimalisir parktik tax avoidance.

Profitabilitas juga diduga mempengaruhi praktik tax avoidance. Profitabilitas merupakan tingkat keuntungan yang dapat dihasilkan perusahaan ketika menjalankan kegiatan operasionalnya. Perusahaan yang memiliki profitabilitas yang tinggi mampu memposisikan diri dalam tax planing yang mengurangi jumlah beban kewajiban perpajakannya (Damayanti dan Susanto, 2015).

Indikasi lain perusahaan melakukan tax avoidance bisa juga dilihat dari kebijakan pendanaan yang diambil perusahaan. Salah satu kebijakan pendanaan itu adalah kebijakan leverage. Leverage merupakan rasio yang memberikan gambaran besarnya utang yang 
dimiliki untuk membiayai aktivitas perusahaan. Ketika perusahaan lebih mengandalkan pembiayaan utang daripada pembiayaan ekuitas untuk kegiatan operasi, perusahaan akan memiliki tarif pajak efektif yang rendah. Selanjutnya Wijayanti dan Merkusiwati (2017) juga mengungkapkan perusahaan yang memiliki leverage yang tinggi akan mendapatkan insentif pajak atas beban bunga yang dapat dimanfaatkan untuk memperkecil beban pajak.

Berdasarkan uraian di atas, maka tujuan penelitian ini adalah untuk mengetahui dan menganalisis pengaruh koneksi politik, intensitas aset tetap, komisaris independen, profitabilitas dan leverage terhadap tax avoidance pada perusahaan sektor perbankan yang terdaftar di Bursa Efek Indonesia periode 2014-2018.

\section{KERANGKA TEORITIS DAN PENGEMBANGAN HIPOTESIS}

\section{Possitive Accounting Theory}

Possitive accounting theory menjelaskan mengenai kebijakan akuntansi dan praktiknya dalam perusahaan serta bagaimana memprediksi kebijakan apa yang akan dipilih manajer dalam kondisi tertentu dimasa yang akan datang. Menurut Scott (2009) postive accounting theory memberikan kebebasan kepada perusahaan untuk memilih salah satu alternatif kebijakan akuntansi untuk meminimalkan biaya kontrak dan memaksimalkan nilai perusahaan. Dengan adanya kebebasan, manajer memiliki kecenderungan melakukan suatu tindakan yang oportunis, yaitu bersifat menguntungkan dan memaksimalkan kepuasan perusahaan (Scott, 2009). Positive accounting theory merumuskan tiga hipotesis yang menjadi dasar motivasi manajer melakukan tindakan opotunistik, yaitu:

a. Hipotesis program bonus (Bonus plan hypothesis)

Perusahaan dengan orientasi bonus plan akan cenderung untuk memilih metode akuntansi yang dapat meningkatkan laba yang dilaporkan pada periode berjalan. Ini dilakukan untuk memaksimalkan bonus yang akan mereka peroleh karena seberapa besar tingkat laba yang dihasilkan seringkali dijadikan dasar dalam mengukur keberhasilan kinerja.

b. Hipotesis perjanjian utang (Debt covenant hypothesis)

Hipotesis ini berkaitan dengan syarat-syarat yang harus dipenuhi perusahaan di dalam perjanjian utang (debt covenant). Sebagian besar perjanjian utang mempunyai syarat-syarat yang harus dipenuhi peminjam selama masa perjanjian. Pelanggaran terhadap perjajian utang dapat menimbulkan suatu biaya serta dapat menghambat kinerja manajemen.

c. Hipotesis biaya politik (Political cost hypothesis)

Dalam hipotesis ini dinyatakan bahwa semakin besar biaya politis yang dihadapi oleh perusahaan maka semakin besar pula kecenderungan perusahaan menggunakan pilihan metode akuntansi yang dapat mengurangi laba, karena perusahaan yang memiliki tingkat laba yang tinggi dinilai akan mendapatkan perhatian yang luas dari kalangan konsumen dan media yang nantinya juga akan menarik perhatian pemerintah dan regulator sehingga menyebabkan biaya politik meningkat.

Dari ketiga hipotesis di atas jika dikaitkan dengan praktik tax avoidance, maka hipotesis biaya politik (political cost) yang dapat menggambarkan penelitian ini, karena dalam undang-undang perpajakan dijelaskan bahwa besarnya pajak yang harus dibayar berdasarkan laba yang diperoleh perusahaan. Artinya semakin besar laba yang diperoleh perusahaan akan semakin besar pula beban pajak yang harus disetorkan ke kas negara. Kondisi inilah yang 
memotivasi manajemen untuk melakukan praktik manajemen laba dengan motif pajak, yaitu untuk mempengaruhi besarnya pajak yang harus dibayar dengan cara menurunkan laba untuk mengurangi beban pajak.

\section{Teori Regulasi}

Teori Regulasi berpendapat bahwa dibutuhkan aturan atau ketentuan dalam akuntansi. Pemerintah dibutuhkan peranannya untuk mengatur ketentuan terhadap apa dan bagaimana yang harus dilakukan perusahaan untuk menentukan informasi. Menurut Scott (2009) terdapat dua jenis teori regulasi, yaitu:

a. The public interest theory

Teori ini menjelaskan bahwa regulasi terjadi karena tuntutan publik dan muncul sebagai koreksi atas kegagalan pasar. Oleh karena itu regulasi harus dapat memaksimalkan kesejahteraan sosial.

b. The interest group theory

Teori ini menjelaskan bahwa regulasi adalah hasil loby dari beberapa individu atau kelompok yang mempertahankan dan menyampaikan kepentingan mereka kepada pemerintah.

Hubungan teori ini dengan praktik tax avoidance adalah adanya konsekuensi ekonomi yang menjadi dasar terjadinya proses politik dalam penyusunan standar setting sehingga proses politik merupakan usaha yang dilakukan oleh orang atau kelompok yang memiliki kepentingan untuk melakukan loby dalam memaksimalkan utilitasnya.

\section{Pengembangan Hipotesis}

\section{Pengaruh koneksi politik terhadap taxa avoidance}

Perusahaan yang memiliki koneksi politik akan mendapatkan perlindungan dari pemerintah, memiliki akses yang mudah untuk mendapatkan pinjaman modal, memiliki risiko audit pajak yang rendah menyebabkan perusahaan menjadi lebih agresif untuk melakukan perencanaan pajak yang mempengaruhi penurunan transparansi keuangan. Berbagai jenis hak istimewa dapat diperoleh oleh suatu perusahaan dengan koneksi politik bahkan ketika krisis keuangan menimpa perusahaan akan dengan mudah menerima bailout dari pemerintah (Kim dan Zhang, 2016). Wahab et al., (2017) menemukan bahwa perusahaan yang terhubung secara politis membayar pajak lebih rendah dibandingkan dengan perusahaan lain yang tidak memiliki koneksi politik. Dengan demikian dapat dirumuskan hipotesis sebagai berikut:

$\mathbf{H}_{1}=$ Koneksi politik berpengaruh terhadap tax avoidance .

\section{Pengaruh intensitas aset tetap terhadap tax avoidance}

Perusahaan yang memutuskan untuk berinvestasi dalam bentuk aset tetap dapat mengubah biaya depresiasi sebagai biaya yang dapat mengurangi laba kena pajak, yang pada akhirnya akan menurunkan total pajak yang seharusnya dibayar. Menurut Martani et al., (2012) aset tetap memiliki masa manfaat lebih dari satu periode dan seiring dengan pemakaian aset tetap tersebut maka kemampuan potensialnya untuk menghasilkan pendapatan akan berkurang. Sebagaimana yang ditunjukkan oleh Purwanti dan Sugiyarti (2017) semakin tingi nilai 
intensitas aset tetap yang dimiliki perusahaan menyebabkan semakin meningkat aktivitas tax avoidance.

$\mathbf{H}_{2}=$ Intensitas aset tetep berpengaruh terhadap tax avoidance

\section{Pengaruh komisaris independen terhadap tax avoidance}

Undang-undang nomor 40 tahun 2007 tentan Perseroan Terbatas menyebutkan bahwa komisaris independen diangkat berdasarkan keputusan RUPS dari pihak yang tidak terafiliasi dengan pemegang saham utama, anggota direksi atau anggota dewan komisaris lainnya. Persyaratan mengenai komisaris independen yang harus ada dalam jajaran komisaris menunjukkan bahwa peranan dari komisaris independen sangat penting bagi perusahaan. Keberadaan komisaris independen diharapkan dapat bersikap netral terhadap segala kebijakan yang dibuat oleh direksi sehingga mendorong perusahaan untuk mengungkapkan informasi yang luas terhadap semua stakeholders. Kehadiran komisaris independen dalam perusahaan dapat meningkatkan pengawasan terhadap kinerja dewan direksi serta memperketat pengawasan terhadap manajemen (Wijayanti dan Merkusiwati, 2017). Alvyani (2016) menyebutkan semakin banyak jumlah komisaris independen, maka semakin besar pengaruhnya untuk melakukan pengawasan kinerja manajemen.

$\mathbf{H}_{3}=$ Komisaris independen berpengaruh terhadap tax avoidance. .

\section{Pengaruh profitabilitas terhadap tax avoidance}

Profitabilitas merupakan salah satu indikator untuk menilai kemampuan perusahaan dalam memperoleh laba. Penelitian Aminah et al., (2017) telah menunjukkan bahwa perusahaan dengan profitabilitas tinggi kemungkinan besar terlibat dalam praktik tax avoidance untuk mengurangi kewajiban pajak mereka. Pernyataan tersebut didukung hasil penelitian Damayanti dan Susanto (2015) dimana laba yang diperoleh perusahaan akan dikelola dengan sebaik mungkin oleh manajemen, salah satunya caranya adalah melakukan perencanaan pajak.

$\mathbf{H}_{\mathbf{4}}=$ Profitabilitas berpengaruh terhadap tax avoidance.

\section{Pengaruh leverage terhadap tax avoidance}

Perusahaan yang menggunakan utang sebagai alternatif pendanaan operasionalnya akan menyebabkan timbulnya beban bunga yang harus dibayar. Dalam peraturan perpajakan pasal 6 ayat 1 angka 3 undang-undang nomor 38 tahun 2008, bunga pinjaman merupakan biaya yang dapat dikurangkan terhadap penghasilan kena pajak perusahaan. Perusahaan dengan jumlah utang yang lebih banyak memiliki nilai tax effecitive rate yang lebih rendah karena pengeluaran biaya bunga akan mengurangi biaya pajak yang akan dikeluarkan oleh perusahaan (Noor, Fadzillah, dan Mastuki, 2010). Salaudeen dan Ejeh (2018) juga menjelaskan bahwa perusahaan lebih memilih pembiayaan utang daripada pembiayaan ekuitas karena dapat memanfaatkan bunga yang ada.

H5 = Leverage berpengaruh terhadap tax avoidance. 


\section{METODE PENELITIAN}

\section{Desain Penelitian}

Metode penelitian yang digunakan adalah metode kuantitatif. Menurut Sugiyono (2017) metode kuantitatif adalah metode penelitian yang berlandaskan pada falsafah positivisme, digunakan untuk meneliti pada populasi atau sampel tertentu, pengumpulan data menggunakan instrumen penelitian, analisis data bersifat kuantitatif atau statistik dengan tujuan untuk menggambarkan dan menguji hipotesis yang telah ditetapkan.

\section{Populasi dan Sampel}

Semua perusahaan sektor perbankan yang terdaftar di BEI periode 2014 sampai 2018 menjadi populasi dalam penelitian ini. Penentuan sampel dilakukan dengan metode purposive sampling. Menurut Sugiyono (2017) purposive sampling adalah teknik penentuan sampel dengan pertimbangan tertentu. Langkah yang dilakukan adalah dengan cara menentukan kriteria tertentu. Adapun kriteria yang dijadikan penentuan sampel adalah sebagai berikut:

a. Perusahaan sektor perbankan yang terdaftar di Bursa Efek Indonesia periode 2014-2018.

b. Publikasi laporan keuangan menggunakan satuan mata uang rupiah.

c. Perbankan memiliki laba positif.

d. Data yang berkaitan dengan variabel penelitian lengkap dan tersedia dalam laporan tahunan perbankan periode 2014-2018.

\section{Pengukuran Variabel Penelitian}

Menurut Pohan (2016) tax avoidance adalah upaya penghindaran pajak yang dilakukan secara legal dan aman bagi wajib pajak karena tidak bertentangan dengan ketentuan perpajakan, dimana metode dan teknik yang digunakan cenderung memanfaatkan kelemahankelemahan (grey area) yang terdapat dalam undang-undang dan peraturan perpajakan itu sendiri untuk memperkecil jumlah pajak terutang. Tax avoidance diukur menggunakan effective tax rate (ETR).

$$
\text { ETR }=\frac{\text { Total Beban Pajak }}{\text { Laba Sebelum Pajak }} \times 100 \%
$$

ETR memiliki arah yang berlwanan dengan tax avoidance. Dimana semakin tinggi presentase nilai ETR yang mendekati tarif pajak penghasilan badan sebesar $25 \%$ akan mengindikasikan semakin rendah tingkat tax avoidance. Sebaliknya jika presentase ETR semakin rendah akan mengindikasikan tax avoidance semakin tinggi. Sehingga persamaan untuk tax avoidance adalah TA = (-ETR).

Koneksi politik adalah suatu kondisi dimana terjalin suatu hubungan antara pihak tertentu dengan pihak yang memiliki kepentingan dalam politik yang digunakan untuk mencapai suatu hal tertentu yang dapat menguntungkan kedua belah pihak (Purwanti \& Sugiyarti, 2017). Untuk menentukan adanya koneksi politik digunakan kriteria sebagai berikut:

a. Perusahaan perbankan merupakan BUMN atau BUMD yang terdaftar di Bursa Efek Indonesia. 
b. Direktur, komisaris, atau dewan direksi berafiliasi dengan partai politik.

c. Direktur, komisaris, atau dewan direksi merupakan pejabat pemerintah dalam periode tersebut.

Dalam menentukan perusahaan memiliki koneksi politik atau tidak digunakan variabel dummy dengan memberikan nilai 1 untuk perusahaan perbankan yang memenuhi indikator atau kriteria di atas, dan nilai 0 jika tidak memenuhi indikator atau kriteria di atas.

Intensitas aset tetap memberikan gambaran besarnya jumlah investasi aset tetap yang dilakukan perusahaan. Intensitas aset tetap dapat diukur denga menggunakan rumus sebagai berikut (Darmadi \& Zulaikha, 2013):

$$
\text { IAT }=\frac{\text { Total Aset Tetap }}{\text { Total Aset }} \times 100 \%
$$

Menurut Cahyono et al., (2016) komisaris independen adalah seorang yang tidak terafiliasi dengan segala hal dengan pemegang saham pengendali, tidak memiliki hubungan afiliasi dengan direksi atau dewan komisaris serta tidak menjabat sebagai direktur pada suatu perusahaan yang terkait dengan perusahaan pemilik menurut peraturan yang dikeluarkan BEI. Komisaris independen dapat diukur dengan perbandingan antara jumlah komisaris independen dengan total anggota dewan komisaris (Cahyono et al., 2016).

$$
\mathrm{KI}=\frac{\text { Jumlah Komisaris Independen }}{\text { Jumlah Dewan Komisaris }}
$$

Profitabilitas merupakan salah satu ukuran kinerja dalam menggambarkan kemampuan perusahaan untuk memperoleh laba dalam suatu periode. Selain itu profitabilitas juga dapat digunakan untuk mengetahui efektivitas manajemen dalam menggunakan asetnya. Variabel profitabilitas diukur dengan return on asset:

$$
\text { ROA }=\frac{\text { Laba Bersih }}{\text { Total Aset }} \times 100 \%
$$

Menurut Ariawan dan Setiawan (2017) leverage adalah tingkat hutang yang dimiliki oleh perusahaan untuk membiayai aktivitas operasinya. Variabel leverage diukur dengan menggunakan debt to equity ratio, yaitu dengan cara total utang dibagi total ekuitas.

$$
\text { Leverage }=\frac{\text { Total Utang }}{\text { Total Ekuitas }} \times 100 \%
$$

\section{Model Analisis Data}

Analisis data yang digunakan terdiri dari beberapa, diantaranya statistik deskriptif, uji asumsi klasik, uji hipotesis dan uji koefisien determinasi. Adapun model persamaan regresi yang digunakan adalah: 


$$
\text { TA }=\alpha+\beta 1 D K P+\beta_{2} I A T+\beta_{3} K I+\beta_{4} P R O+\beta_{5} L E V+e . .
$$

dimana:

$\begin{array}{ll}\text { TA } & : \text { Tax Avoidance } \\ \alpha & : \text { Konstanta } \\ \beta_{1}-\beta_{5} & : \text { Koefisien Regresi } \\ \text { DKP } & : \text { Koneksi Politik } \\ \text { IAT } & : \text { Intensitas Aset Tetap } \\ \text { KI } & : \text { Komisaris Independen } \\ \text { PRO } & : \text { Profitabilitas } \\ \text { LEV } & : \text { Leverage } \\ \mathrm{e} & : \text { Error }\end{array}$

HASIL DAN PEMBAHASAN

Deskripsi Objek Penelitian

Tabel 2 : Kriteria Penentuan Sampel

\begin{tabular}{clc}
\hline No & \multicolumn{1}{c}{ Kriteria } & $\begin{array}{c}\text { Jumlah } \\
\text { Pengamatan }\end{array}$ \\
\hline 1 & $\begin{array}{l}\text { Populasi (Perusahaan sektor perbankan yang terdaftardi BEI } \\
\text { periode 2014-2018) }\end{array}$ & 215 \\
\hline 2 & $\begin{array}{l}\text { Publikasi laporan keuangan tidak menggunakan satuan mata } \\
\text { uang rupiah }\end{array}$ & 0 \\
3 & Perbankan yang mengalami laba negatif (rugi) & $(26)$ \\
4 & Perbankan yang menerbitkan laporan keuangan tidak lengkap & $(15)$ \\
5 & Data Outlier & $(2)$ \\
\hline & Total Pengamatan & $\mathbf{1 7 2}$ \\
\hline
\end{tabular}

Sumber: Data diolah, SPSS 2021

Berdasarkan tabel di atas dapat dijelaskan bahwa jumlah perusahaan sektor perbankan yang listing di BEI tahun 2014 yaitu 40 bank, tahun 2015 sebanyak 42 bank, tahun 2016 dan 2017 masing-masing berjumlah 44 bank dan tahun 2018 sebanyak 45 bank, sehingga total populasi berjumlah 215 perbankan. Namun dari 215 populasi tersebut sebanyak 15 laporan keuangan yang tidak lengkap, 26 mengalami laba negatif dan data outlier sebanyak 2 , sehingga total yang tersisa adalah 172 pengamatan.

\section{Hasil Uji Asumsi Klasik}

Tujuan dilakukan pengujian asumsi klasik adalah untuk memastikan data yang digunakan terdistribusi dengan normal dan memastikan model dalam regresi yang digunakan tidak mengalami heterokedastisitas, autokorelasi serta multikolinieritas. Berikut ini adalah hasil uji asumsi klasik: 
Tabel 3 : Uji Asumsi Klasik

\begin{tabular}{|c|c|c|c|}
\hline \multirow{2}{*}{ Variabel } & \multicolumn{2}{|c|}{ Collinearity Statistics } & \multirow{2}{*}{ Heteroskedastisitas } \\
\hline & Tolerance & VIF & \\
\hline Koneksi Politik & ,898 & 1,113 & ,688 \\
\hline Intensitas Aset Tetap & ,932 & 1,073 & 631 \\
\hline Komisaris Independen & ,966 & 1,035 & ,949 \\
\hline Profitabilitas & ,842 & 1,187 & ,764 \\
\hline Leverage & ,866 & 1,154 & ,459 \\
\hline Normalitas-Asymp.Sig. (2-tailed) & \multicolumn{3}{|c|}{,095 } \\
\hline Autokorelasi (Durbin-Watson) & \multicolumn{3}{|c|}{1,498} \\
\hline
\end{tabular}

Sumber: Data diolah, SPSS 2021

Berdasarkan tabel di atas diperoleh nilai Asymp. Sig (2-tailed) sebesar 0,095. Karena nilai Asymp. Sig (2-tailed) lebih besar dari 0,05 (0,095 > 0,05), maka dapat disimpulkan data yang digunakan terdistribusi dengan normal. Hasil uji multikolinieritas menunjukkan bahwa variabel independen terbebas dari multikolinieritas, hal ini dapat dilihat dari nilai tolerance dari semua variabel lebih besar dari $0,1(0,898,0,932,0,966,0,842,0,866>0,1)$. Selain itu nilai VIF dari semua variabel independen juga lebih kecil dari $10(1,113,1,073,1,035,1,187$, $1,154<10)$. Berdasarkan tabel pengujian heteroskedastisitas di atas dapat dilihat semua nilai Sig. (2-tailed) variabel independen lebih besar dari $0,05(0,688,0,631,0,949,0,764,0,459>$ $0,05)$ yang berarti tidak terjadi heteroskedastisitas antar variabel independen dalam model regresi. Dan selanjutnya, berdasarkan hasil pengujian nilai Dubin Watson yang dihasilkan dari model regresi adalah 1,498. Nilai DW tersebut berada diantara -2 sampai +2 yang artinya dapat disimpulkan dalam model regresi ini tidak terjadi autokorelasi.

\section{Hasil Regresi Linier Berganda dan Uji Hipotesis}

Tabel 4 : Uji t

\begin{tabular}{|c|c|c|c|c|}
\hline Variabel & B & Sig. & $\begin{array}{c}\text { Hipotesi } \\
\text { s }\end{array}$ & Kesimpulan \\
\hline (Constanta) & 33,248 &, 000 & & \\
\hline Koneksi Politik & $-2,124$ &, 023 & $\mathrm{H} 2$ & Berpengaruh (diterima) \\
\hline Intensitas Aset Tetap &,- 521 &, 010 & $\mathrm{H} 3$ & Berpengaruh (diterima) \\
\hline Komisaris Independen & 1,126 &, 775 & $\mathrm{H} 4$ & Berpengaruh \\
\hline Profitabilitas & $-1,448$ & ,003 & $\mathrm{H} 5$ & (ditolak) \\
\hline Leverage &,- 762 & ,000 & H6 & Berpengaruh (diterima) \\
\hline & & & & Berpengaruh (diterima) \\
\hline $\begin{array}{l}\text { Koefisien Determinasi } \\
\text { (Adjusted R Square) }\end{array}$ & \multicolumn{4}{|c|}{,145 } \\
\hline Uji F (Sig.) & \multicolumn{4}{|c|}{,000 } \\
\hline F-hitung & \multicolumn{4}{|c|}{6,789} \\
\hline
\end{tabular}

Sumber: Data diolah, SPSS 2021 
Dari tabel di atas dapat dilihat nilai adjusted $R$ square sebesar 0,145 atau 14,5\%, hal ini menunjukkan bahwa variabel independen yaitu koneksi politik, intensitas aset tetap, komisaris independen, profitabilitas dan leverage memiliki kontribusi atau pengaruh sebesar $14,5 \%$ terhadap praktik tax avoidence yang dilakukan oleh perbankan yang terdaftar di Bursa Efek Indonesia. Semtara sisanya 85,5\% dipengaruhi oleh variabel independen lain yang tidak menjadi objek dalam penelitian ini.

Tabel di atas menunjukkan nilai F-hitung sebesar 6,789 dengan nilai signifikan 0,000. Nilai signifikansinya lebih kecil dari $0,05(0,000<0,05)$ sehingga dapat diartikan variabel independen yaitu koneksi politik, intensitas aset tetap, komisaris independen, profitabilitas dan leverage secara bersama-sama atau simultan berpengaruh terhadap tax avoidance pada perusahaan perbankan yang listing di BEI.

\section{Pembahasan}

\section{Koneksi politik berpengaruh terhadap tax avoidance}

Koefisien regresi koneksi politik sebesar -2,124 dengan tingkat signifikansi 0,023 lebih kecil dari $\alpha=0,05(0,023<0,05)$ dengan demikian koneksi politik memiliki pengaruh terhadap ETR dengan arah negatif. Arah negatif dapat diartikan apabila perbankan memiliki koneksi politik, maka nilai effective tax rate (ETR) akan semakin rendah. Nilai ETR yang rendah mengindikasikan terjadinya peningkatan tax avoidance. Sehingga dapat disimpulkan koneksi politik berpengaruh terhadap tax avoidance.

Hasil ini memberikan bukti empiris bahwa dengan adanya koneksi politik yang dimiliki akan meningkatkan kecenderungan perbankan melakukan praktik tax avoidance, atau dengan kata lain hubungan politik yang kuat akan dimanfaatkan untuk memperoleh keuntungan dalam hal efisiensi beban pajak. Penelitian ini sejalan dengan temuan Kim dan Zhang (2016) bahwa perusahaan yang memiliki koneksi politik akan lebih agresif dalam pajak daripada perusahaan yang tidak memiliki koneksi politik. Hal yang sama ditemukan, Wicaksono (2017), Abdul Wahab et al., (2017) dan Christensen et al., (2015).

Setiap perusahaan berusahan membangun koneksi politik yang kuat dengan cara menempatkan pihak-pihak yang memiliki kedekatan dengan pemerintah, sehingga memiliki akses terhadap struktur pemerintahan atau yang memiliki kekuasaan politik. Ini dikarenakan perusahaan akan memiliki resiko deteksi yang rendah sebab politisi atau penguasa akan memberikan perlindungan terhadap perusahaan tersebut. Selain itu keuntungan lain yang diperoleh perusahaan, seperti kemudahan dalam memperoleh pinjaman modal, resiko pemeriksaan pajak yang kecil, informasi yang akurat mengenai perubahan peraturan perpajakan, bahkan akan memperoleh akses ke pemerintah pusat. Menurut Wicaksono (2017)koneksi politik yang dimiliki oleh perusahaan digunakan untuk meloby pemerintah untuk menghindari pemeriksaan pajak, pengajuan pengurangan denda pajak maupun tindakan lain yang tergolong tax evasion atau tax agreesiveness.

Pada perusahaan perbankan yang memiliki koneksi politik yang kuat seperti bank BUMN/BUMD dimana mayoritas sahamya dimiliki oleh pemerintah pusat atau pemerintah daerah justru melakukan praktik tax avoidance, meskipun dalam Peraturan Menteri Keuangan Nomor: 71/PMK.03/2010 menjelaskan BUMN dikategorikan wajib pajak badan yang memiliki resiko rendah (Utari \& Supadmi, 2017). Hasil penelitian ini juga membuktikan 
bahwa pada negara berkembang termasuk indonesa, koneksi politik adalah fenomena yang umum dilakukan karena sejak zaman pemerintahan Presiden Soeharto samapi pemerintahan Joko Widodo bisa kita lihat pengisian komisaris dihampir semua Badan Usaha Milik Negara (BUMN) diisi oleh orang-orang yang memiliki hubungan dekat dengan pemerintah seperti para relawan maupun anggota partai politik.

\section{Intensitas aset tetap berpengaruh terhadap tax avoidance}

Variabel intensitas aset tetap memiliki nilai koefisien regresi sebesar -0,521 dengan taraf signifikansi 0,010 lebih kecil dari $\alpha=0,05(0,010<0,05)$. Dengan demikian intensitas aset tetap memiliki pengaruh negatif terhadap effective tax rate (ETR). Arah negatif ini dapat dimaknai jika nilai intensitas aset tetap meningkat, maka nilai ETR akan semakin rendah. Nilai ETR yang rendah mengindikasikan terjadinya peningkatan tax avoidance. Dengan demikian intensitas aset tetap berpengaruh terhadap tax avoidance.

Jumlah aset tetap yang besar akan meningkatkan praktik tax avoidance karena aset tetap yang besar akan diikuti dengan peningkatan beban penyusutan, sehingga beban penyustan yang besar akan dimanfaatkan untuk mengurangi penghasilan kena pajak. Atau dengan kata lain jumlah aset tetap yang besar bisa dijadikan sebagai salah satu alternatif untuk melakukan penghindaran pajak (tax avoidance). Hasil penelitian yang sama ditemukan Darmadi dan Zulaikha (2013) dimana perusahaan dengan intensitas aset tetap yang besar kemungkinan akan melakukan tax avoidance.

Menurut Purwanti dan Sugiyarti (2017) pemegang saham meninginkan manajer untuk bisa menghasilkan dan mengelola keuntungan atas aset tetap dengan baik, sehingga biaya yang dikeluarkan untuk membayar pajak tidak terlalu besar. Dalam manajemen pajak, intensitas aset tetap berpotensi menekan beban pajak perusahaan, hal tersebut terjadi karena beban penyusutan yang bersifat deductible axpense akan berperan sebagai pengurang laba perusahaan yang dijadikan dasar pengenaan pajak (Sundari dan Aprilina, 2017). Oleh karenanya intensitas aset tetap yang tinggi sengaja dimanfaatkan oleh perusahaan untuk menghindari pajak dengan cara meningkatkan investasi pada aset tetap sehingga dapat memaksimalkan laba perusahaan.

\section{Komisaris independen berpengaruh terhadap tax avoidance}

Variabel komisaris independen koefisien regresi sebesar 1,126 dengan tingkat signifikansi 0,775 lebih besar dari $\alpha=0,05(0,775>0,05)$. Dengan demikian komisaris independen tidak berpengaruh terhadap tax avoidance. Artinya jumlah komisaris independen yang besar belum mampu mencegah dewan direksi untuk melakukan praktik tax avoidance.

Dalam Surat Keputusan Direksi PT Bursa Efek Indonesia Nomor: Kep.315/BEJ/062000 menjelaskan perusahaan yang tercatat di BEI wajib memiliki komisaris independen yang jumlah proporsionalnya sebanding dengan jumlah saham yang dimiliki oleh bukan pemegang saham pengendali dengan ketentuan jumlah komisaris independen minimal $30 \%$ dari keseluruhan anggota dewan komisaris. Dari semua perusahaan sektor perbankan yang menjadi objek penelitian ini telah memenuhi ketentuan jumlah minimal komisaris independen yaitu $30 \%$, jumlah tersebut ternyata hanya untuk memenuhi peraturan yang di tetapkan BEI. 
Salah satu tugas utama dari komisaris independen adalah melakukan pengawasan dan kontrol terhadap kebijakan yang diambil oleh para direksi sehingga tidak merugikan atau merusak citra perusahaan. Selain itu komisaris independen juga diharapkan tidak terpengaruh dengan kepentingan pemilik saham pengendali. Namun hasil penelitian ini memeberikan bukti empiris bahwa komisaris independen yang dimiliki oleh perbankan belum mampu menjalankan fungsinya secara optimal karena belum mampu mencegah terjadinya praktik tax avoidnace. Hal ini dibenarkan oleh Turyatini (2017) bahwa peran komisaris independen pada fungsi tata kelola perusahaan belum mampu mengatasi konflik kepentingan antar dewan komisaris atau diantara pemegang saham sehingga manajemen cenderung untuk melakukan tindakan yang beresiko.

Temuan penelitian ini sejalan dengan Utari dan Supadmi (2017), Cahyono et al., (2016), Tandean dan Winnie (2016), Annisa dan Kurniasih (2012), yang memberikan bukti bahwa komisaris independen tidak memiliki pengaruh terhadap praktik tax avoidance. Penambahan jumlah komisaris independen mungkin hanya memenuhi ketentuan yang telah ditetapkan oleh BEI, namun dalam hal pengambilan keputusan tetap di dewan direksi sehingga komisaris independen tidak bisa secara langsung mempengaruhi prilaku dari direksi dalam pengambilan keputusan.

\section{Profitabilitas berpengaruh terhadap tax avoidance}

Variabel profitabilitas memiliki nilai koefisien regresi sebesar -1,448 dengan tingkat signifikan aebesar 0,003 lebih kecil dari $\alpha=0,05(0,003<0,05)$. Dengan demikian profitabilitas memiliki pengaruh terhadap ETR dengan arah negatif. Arah negatif dapat diartikan peningkatan profitabilitas akan menurunkan nilai ETR. Penurunan nilai ETR mengindikasikan terjadinya peningkatan tax avoidance. Sehingga dapat disimpulkan profitabilitas memiliki pengaruh terhadap tax avoidance.

Profitabilitas yang tinggi cenderung dimanfaatkan perbankan untuk melakukan praktik tax avoidance, ini dikarenakan dalam undang-undang pajak penghasilan besarnya pajak yang harus ditanggung dihitung berdasarkan besaran laba yang diperoleh perusahaan. Sehingga pofitabilitas diduga menjadi salah satu faktor yang menjadi penentu tinggi rendahnya praktik tax avoidance pada perusahaan sektor perbankan yang terdaftar di BEI.

Chen et al., (2010) menjelaskan bahwa perusahaan yang memiliki profitabilitas tinggi memiliki kesempatan untuk memposisikan diri dalam tax planing untuk mengurangi jumblah beban keawjiban perpajakan. Selanjutnya Noor et al., (2010) menyatakan profitabilitas yang tinggi dari perusahaan akan optimal untuk melakukan perencanaan pajak, oleh karena itu penghindaran pajak akan meningkat. Temuan penelitian ini mendukung temuan Damayanti dan Susanto (2015) yang membuktikan profitabilitas adalah salah satu faktor yang mempengaruhi tax avoidance.

Positive accounting theory menjelaskan bahwa manajemen memiliki kesempatan untuk memilih menggunakan metode akuntansi yang dapat memberikan keuntungan dan nilai tambah bagi perusahaan. Karena profitabilitas memiliki arah positif dengan beban pajak, maka perusahaan akan memilih metode akuntansi yang dapat meminimalkan beban pajak perusahaan, selain itu perusahaan juga akan memanfaatkat celah peraturan perpajakan untuk efisiensi beban pajak. 


\section{Leverage berpengaruh terhadap tax avoidance}

Variabel leverage memiliki nilai koefisien regresi sebesar -0,762 dengan tingkat signifikansi 0,000 lebih kecil dari $\alpha=0,05(0,000<0,05)$. Hal ini memiliki makna leverage memiliki pengaruh terhadap ETR dengan arah negatif. Jik rasio leverage mengalami peningkatan, maka nilai effective tax rate (ETR) akan semakin rendah. Nilai ETR yang rendah mengindikasikan terjadinya peningkatan tax avoidance. Sehingga dapat disimpulkan leverage berpengaruh terhadap tax avoidance.

Semakin tinggi leverage meningidikasikan kecenderungan perbankan melakukan tax avoidance akan meningkat, ini disebabkan karena leverage meningkatkan beban bunga yang dapat dimanfaatan sebagai pengurang laba kena pajak. Sehingga dapat diambil kesimpulan bahwa leverage merupakan salah satu faktor penentu tinggi rendahnya praktik tax avoidance pada perusahaan sektor perbankan.

Menurut Dewi Putriningsih et al., (2018) utang yang menyebabkan munculnya beban bunga dapat menjadi pengurang laba kena pajak, sedangkan deviden yang berasal dari laba ditahan tidak dapat digunakan sebagai pengurang laba. Beban bunga yang dapat digunakan sebagai pengurang laba kena pajak adalah beban bunga yang muncul akibat adanya pinjaman kepada pihak ketiga atau kreditur yang tidak memiliki hubungan denga perusahaan, sebagaimana diatur dalam UU No.36 tahun 2008 pasal 6 ayat 1a dan pasal 18. Utang memberikan banyak manfaat bagi perusahaan jika dapat dikelolah dengan baik seperti memberikan keuntungan yang lebih besar sehingga pengembalian kepada investor akan semakin besar, selain itu penggunaan utang tidak akan menyebabkan bertambahnya pemilik perusahaan dimana jika perusahaan mengeluarkan samham untuk memenuhi kebutuhan pendanaanya akan membuat bertambah pemilik perusahaan sehingga keputusan yang diambil sesuai dengan tujuan perusahaan dan tidak banyak dipengaruhi kepentingan pihak lain.

Temuan penelitian ini mendukung hasil penelitian Ribeiro et al., (2015), Turyatini (2017) yang menyatakan leverage berpengaruh terhadap tax avoidance. Hal yang sama diungkapkan oleh Ariawan dan Setiawan (2017) bahawa perusahaan dengan tingkat leverage yang tinggi cenderung melakukan tax avoidance sebagai akibat dari insentif pajak atas beban bunga yang diterima perusahaan untuk meminimalkan beban pajaknya. Anouar dan Houria (2017) juga menemukan bahwa utang digunakan oleh perusahaan untuk memaksimalkan peluang penghindaran pajak.

\section{KESIMPULAN, KETERBATASAN, DAN SARAN}

Berdasarkan analisis data dan pembahasan hasil penelitian, maka dapat disimpuklan bahwa koneksi politik berpengaruh terhadap tax avoidance, ini bisa diartikan jika perbankan memiliki koneksi politik, maka kecenderungan untuk melakukan praktik tax avoidance akan meningkat. Intensitas aset tetap berpengaruh terhadap tax avoidance, artinya peningkatan jumlah aset tetap akan diikuti dengan peningkatan beban penyusutan, sehingga beban penyusutan yang besar akan dimanfaatkan untuk mengurangi kewajiban pajak. Komisaris independen tidak berpengaruh terhadap tax avoidance, ini memberikan gambaran bahwa besar kecilnya jumlah komisaris independen yang dimiliki oleh perbankan belum mampu mencegah direksi untuk melakukan praktik tax avoidance. Profitabilitas berpengaruh terhadap tax 
avoidance, artinya semakin tinggi profitabilitas, maka kecenderungan untuk melaukan praktik tax avoidance akan meningkat. Leverage berpengaruh terhadap tax avoidance. Degan memiliki leverage yang tinggi maka kecenderungan untuk melakukan tax avoidance akan meningkat.

Terdapat beberapa keterbatasan yang dialami oleh peneliti yang kemunagkinan dapat mempengaruhi hasil penelitian ini. Diantara keterbatasan tersebut adalah sebagai berikut:

a. Penelitian terbatas pada sektor perbankan sehingga hasil penelitian ini tidak bisa digunakan untuk mengeneralisasi praktik tax avoidance pada sektor perusahaan lain yang terdaftar di BEI karena memiliki karakter yang berbeda.

b. Data mengenai koneksi politik hanya diperoleh dari laporan keuangan sehingga informasi yang diperoleh masih terbatas.

c. Penelitian ini menggunakan metode kuantitatif dengan menggunakan data sekunder, dan kemungkinan dapat menghasilkan kesimpulan yang berbeda dengan penelitian yang menggunakan metode kualitatif maupun metode campuran (mix methods).

Peneliti selanjutnya dapat menggunakan sampel perusahaan non perbankan agar dapat mengetahui apakah juga terjadi praktik tax avoidance. Selain itu dapat mempertimbagkan untuk menggunakan variabel lain karena masih banyak faktor yang diduga menjadi alasan perusahaan melakukan tax avoidance. Serta mempertimbangkan untuk menggunakan mix method, berupa survei dan data sekunder agar dapat menggambrakan keadaan yang sebenarnya, khususnya yang berkaitan dengan variabel koneksi politik.

\section{DAFTAR PUSTAKA}

Abdul Wahab, E. A., Ariff, A. M., Madah Marzuki, M., \& Mohd Sanusi, Z. (2017). Political connections, corporate governance, and tax aggressiveness in Malaysia. Asian Review of Accounting, 25(3), 424-451.

Alviyani, K. (2016). Pengaruh Corporate Governance, Karakter Eksekutif, Ukuran Perusahaan, Dan Leverage Terhadap Penghindaran Pajak (Tax Avoidance) (Studi Pada Perusahaan Pertanian dan Pertambangan yang Terdaftar di BEI Tahun 20112014). JOM Fekon, 3(1), 2540-2554.

Aminah, Chairina, \& Sari, Y. Y. (2017). 3 The Influence of Company Size, Fixed Asset Intensity, Leverage, Profitability, and Political Connection To Tax Avoidance. AFEBI Accounting Review, 2(2), 30-43.

Annisa, N. A., \& Kurniasih, L. (2012). Pengaruh Corporate Governance Terhadap Tax Avoidance. Jurnal Akuntansi dan Auditing, 8(2), 95-189.

Anouar, D., \& Houria, Z. (2017). The Determinants of Tax Avoidance within Corporate Groups: Evidence from Moroccan Groups. International Journal of Economics, Finance and Management Sciences, 5(1), 57-65.

Ariawan, I. M. A., \& Setiawan, P. E. (2017). Pengaruh Dewan Komisaris Independen, Kepemilikan Institusional, Profitabilitas dan Leverage Terhadap Tax Aavoidance. EJurnal Akuntansi Universitas Udayana, 18(3), 1831-1859.

Cahyono, D. D., Andini, R., \& Raharjo, K. (2016). Pengaruh Komite Audit, Kepemilikan Institusional, Dewan Komisaris, Ukuran Perusahaan (Size), Leverage (DER) DAN 
Profitabilitas (ROA) Terhadap Tindakan Penghindaran Pajak (Tax Avoidance) Pada Perusahaan Perbankan Yang Listing BEI Periode Tahun 2011 - 2013. Journal Of Accounting, 2, 10.

Chen, S., Chen, X., Cheng, Q., \& Shevlin, T. (2010). Are family firms more tax aggressive than non-family firms? Journal of Financial Economics, 95, 46-61.

Christensen, D. M., Dhaliwal, D. S., Boivie, S., \& Graffin, S. D. (2015). Top management conservatism and corporate risk strategies: Evidence from managers' personal political orientation and corporate tax avoidance: Managers' Political Orientation and Corporate Tax Avoidance. Strategic Management Journal, 36, 1918-1938.

Damayanti, F., \& Susanto, T. (2015). Pengaruh Komite Audit, Kualitas Audit, Kepemilikan Institusional, Risiko Perusahaan Dan Return On Assets Terhadap Tax Avoidance. ESENSI Jurnal Bisnis dan Manajemen, 5(2). Retrieved January 8, 2020, from http://journal.uinjkt.ac.id/index.php/esensi/article/view/2341

Darmadi, I. N. H., \& Zulaikha. (2013). Analisis Faktor Yang Mempengaruhi Manajemen Pajak Dengan Indikator Tarif Pajak Efektif. Diponegoro Journal of Accounting, 2(4), $1-12$.

Dewi Putriningsih, Eko Suyono, \& Eliada Herwiyanti. (2018). Profitabilitas, Leverage, Komposisi Dewan Komisaris, Komite Audit, Dan Kompensasi Rugi Fiskal Terhadap Penghindaran Pajak Pada Perusahaan Perbankan. Jurnal Bisnis dan Akuntansi, 20(2), 77-92.

Dyreng, S. D., Hanlon, M., \& Maydew, E. L. (2010). The Effects of Executives on Corporate Tax Avoidance. The Accounting Review, 85(4), 1163-1189.

Kim, C. F., \& Zhang, L. (2016). Corporate Political Connections and Tax Aggressiveness. Contemporary Accounting Research, 33(1), 78-114.

Martani, D., Veronica, S. N., Wardhani, R., Farahmita, A., \& Tanujaya, E. (2012). Akuntansi Keuangan Menengah Berbasis PSAK. Jakarta: Salemba Empat.

Noor, R. M., Fadzillah, N. S. M., \& Mastuki, N. (2010). Corporate Tax Planning: A Study On Corporate Effective Tax Rates of Malaysian Listed Companies. International Journal of Trade, Economics and Finance, 1(2), 189-193.

Permata, A. D., Nurlaela, S., \& Wahyuningsih, E. M. (2018). Pengaruh Size, Age, Profitability, Leverage dan Sales Growth Terhadap Tax Avoidance. Jurnal Akuntansi dan Pajak, 19(1), 10-20.

Pohan, C. A. (2016). Manajemen Perpajakan Strategi Perencanaan Pajak dan Bisnis. Jakarta: PT.Gramedia Pustaka Utama.

Purwanti, S. M., \& Sugiyarti, L. (2017). Pengaruh Intensitas Aset Tetap, Pertumbuhan Penjualan dan Koneksi Politik Terhadap Tax Avoidance. Jurnal Riset Aakuntansi dan Keuangan, 5(3), 1625-1642.

Ribeiro, A., Cerqueira, A., \& Brandão, E. (2015). The Determinants of Effective Tax Rates: Firms' Characteristics and Corporate Governance. FEP Working Pepers, 48.

Salaudeen, Y. M., \& Ejeh, B. U. (2018). Equity ownership structure and corporate tax aggressiveness: The Nigerian context. Research Journal of Business and Management, 5(2), 90-99. 
Scott, R. W. (2009). Financial Accounting Theory (Fifth Edition.). Toronto: Pearson Prentice Hall.

Sudibyo, Y. A., \& Jianfu, S. (2016). Political Connections, State Owned Enterprises And Tax Avoidance: An Evidence From Indonesia. Corporate Ownership and Control, 13(3). Retrieved January 8, 2020, from http://www.virtusinterpress.org/POLITICALCONNECTIONS-STATE-OWNED.html

Sugiyono. (2017). Metode Penelitian Bisnis. Pendekatan Kuantitatif, Kualitatif, Kombinasi, dan RD. Bandung: CV Alfabeta.

Sundari, N., \& Aprilina, V. (2017). Pengaruh Konservatisme Akuntansi, Intensitas Aset Tetap, Kompensasi Rugi Fiskal Dan Corporate Governanace Terhadap Tax Avoidance. JRAK: Jurnal Riset Akuntansi dan Komputerisasi Akuntansi, 8(1), 85-109.

Tandean, V. A., \& Winnie. (2016). The Effect of Good Corporate Governance on Tax Avoidance: An Empirical Study on Manufacturing Companies Listed in IDX period 2010-2013. Asian Journal of Accounting Research, 1, 28-38.

Turyatini, T. (2017). The Analysis of Tax Avoidance Determinant on The Property and Real Estate Companies. Jurnal Dinamika Akuntansi, 9(2), 143-153.

Utari, N. K. Y., \& Supadmi, N. L. (2017). Pengaruh Corporate Governance, Profitabilitas Dan Koneksi Politik Pada Tax Avoidance. E-Jurnal Akuntansi Universitas Udayana, 18(3), 2202-2230.

Wicaksono, A. P. N. (2017). Koneksi Politik dan Aggresivitas Pajak: Fenomena di Indonesia. Akuntabilitas: Jurnal Ilmu Akuntansi, 10(1), 167-180.

Wijayanti, Y. C., \& Merkusiwati, N. K. L. A. (2017). Pengaruh Proporsi Komisaris Independen, Kepemilikan Institusional, Leverage, Dan Ukuran Perusahaan Pada Penghindaran Pajak. E-Jurnal Akuntansi Universitas Udayana, 20(1), 699-728.

https://www.idx.co.id/ (Diakses: 9 September 2020)

https://www.kemenkeu.go.id/ (Diakses: 23 September 2020) 